\title{
Cosmopolitanism as Hospitality: Revisiting Identity and Difference in Cosmopolitanism
}

\author{
Gideon Baker*
}

For many cosmopolitans, an emergent global civil society is reframing the relationship between the universal and particular in world politics in ways that do justice to both. This article disputes this claim, finding that the concept of global civil society shares the same fundamental problem as state sovereignty, namely that it is better at articulating global identity than difference because it reproduces in different form statist attempts to describe a universal structure of particularity. It then argues that to avoid reducing difference to identity while remaining true to the cosmopolitan impulse to ethical universality, that is, to recognition of moral obligations to foreigners, it is necessary to take cosmopolitanism as synonymous with an ethics of hospitality enabling a nondialectical account of identity and difference in cosmopolitanism. As Derrida affirms, hospitality deconstructs the binary of identity and difference in our ethical relations with strangers. This dialectic-defying quality of cosmopolitanism-ashospitality requires a greater decisionism than dialectical liberalcosmopolitanism, turning cosmopolitanism away from the pure ethics of its liberal variants and transforming it into an ethicopolitics. KeYwORDs: cosmopolitanism; hospitality; identity; difference; Derrida

The debate between liberal cosmopolitans and their critics rebounds monotonously between the rock of universalism-imperialistic projections of identity-and the hard place of particularity-essentializing projections of difference and otherness. The call to transcend international plurality in the name of putative universals such as individual right is accused of giving carte blanche to the so-called neoimperialism of the liberal interventionists. Yet, conversely, every attempt

*Department of Politics and Public Policy, Griffith University, Queensland, Australia. E-mail: g.baker@griffith.edu.au 
to leave the world as it is seems justifiable only by twisting the fact of pluralism into a universal value. ${ }^{1}$ Universalisms persistently struggle with the accusation that they are merely a Trojan horse for a particular (but would-be hegemonic) way of life-universalists are forced to admit that they always carry with them "a clump of their native soil."2 Yet the valorization of difference is also constantly under attack for risking a descent into irresponsible relativism-in Habermas's terms, for fundamentally failing to provide an answer to the question "Why fight?" against injustice while at the same time exhibiting the performative contradiction of granting universal normative status to difference. ${ }^{3}$

This universality-particularity or identity-difference debate endlessly repeats its now depressingly familiar moves, with even attempts at accommodation between the two poles reproducing the underlying dialectical approach in the sense of ultimately seeking a synthesis between them. Thus the international society or English School perspective, for example, despite promising a via media of universal and particular in the form of a global agreement to disagree, continues with an either-or sense of the opposition between these poles as we can see from Hedley Bull's reluctant conclusion, in The Anarchical Society, that international order, premised on difference, must in the final analysis trump international-order-wrecking "world justice."

Yet offering to break this deadlock, or so it appears to many cosmopolitans, is an emergent global civil society that is reframing the relationship between the universal and particular in ways conducive to cosmopolitan political community. This reframing of identity and difference within the theory and practice of global civil society is seen by many cosmopolitans as at last doing justice to both universality and particularity in world politics. Global civil society is held to be at once more genuinely universal than the society of states and yet also more authentically particularistic; more universal in the sense of displacing territorially bounded, national forms of belonging with deterritorialized, transnational identities; more particularistic in the sense of replacing the universal structure of difference characteristic of state sovereignty with a more genuinely pluralistic expression of global diversity (ranging from new social movements to indigenous rebellions and everything in between). This article disputes this picture, finding that the concept of global civil society shares the same fundamental problem as that of state sovereignty-namely that it is better at articulating global identity than difference because it reproduces only in different form the statist attempt to describe a universal structure of particularity. What statist and globalist conceptions of political community therefore share, I argue, is a largely unhelpful dialectical approach to the question of how to find a place for both identity and difference (where dialectics is understood as seeking to synthesize identity and difference by subsuming the particular within the universal). 
What is an appropriate response to this difference-denying logic at work in accounts of world politics? Should the cosmopolitanism imaginary itself, as a totalizing account of universal humanity within which singularities are subordinate, stand condemned? ${ }^{5}$ Since identity and difference are mutually constitutive, attempts to transcend the dichotomy in the direction of singularity, as much as in the name of universality, are fundamentally flawed. Is it then possible to articulate a cosmopolitanism that resists the false hope of a "beyond" to the binary of identity and difference? Can we articulate a cosmopolitan ethics that denies neither universals nor singularities and which opens up the political space necessary to negotiate between them?

The argument here is that we can. The productive tension between identity and difference at the heart of cosmopolitan ethics is captured by the ethics of hospitality, where our awareness of the identity of the stranger as a fellow human being seeking refuge is opposed by the irreducible difference of the stranger as Other-someone who, as a guest in a home not his own, suffers the violence of assimilation. It is, of course, Jacques Derrida (inspired, in turn, by Emmanuel Levinas), who has considered the ethics of hospitality in these terms, and it is to his account, and its implications for rethinking identity and difference in cosmopolitanism, that we turn in the second part of the article. If Derrida is right that, as the name for that which opens itself up to the Other, ethics is hospitality, then cosmopolitanism is hospitality too-and thinking cosmopolitanism through hospitality becomes a necessary rather than contingent exercise in cosmopolitan thought.

Admittedly, cosmopolitanism comes attached to a now ancient attempt—central to Western philosophy, if we are to believe Levinasto think the other from the standpoint of the Same. ${ }^{6}$ So does hospitality, which, tied to this cosmopolitan tradition and its thinking about the stranger, has always been limited, offered subject to strict and domesticating conditionalities by a sovereign host. And yet, as Derrida has indicated with his thinking on "unconditional hospitality" to which we will return later, deconstructing the cosmopolitan "heritage" of the West does not mean moving entirely beyond it-deconstruction is parasitical on that which it deconstructs. So cosmopolitanism and hospitality must necessarily be the starting point in rethinking the place of the stranger to our politics; it is never possible to begin entirely anew. Indeed, it may not be necessary to start anew. In Totality and Infinity, which Derrida has rightly identified as an "immense treatise on hospitality," Levinas gives us the exact opposite of a totalizing account of the stranger-a vision of hospitality infused with difference. ${ }^{7}$ Levinas argues for the primacy of the idea of infinity (that which is premised upon the transcendent or unsurpassable nature of the particular and the personal and which is "produced by the relationship of the same with the other") over totality, specifically, for an idea of subjectivity "as 
welcoming the Other, as hospitality; in [which] the idea of infinity is consummated."

So hospitality is not reducible to the universalizing power of the host. But neither is it reducible to the otherness of the guest, either. ${ }^{9}$ In other words, there are particularly good reasons for foregrounding hospitality when rethinking identity-difference in cosmopolitanism nondialectically. Returning to the argument of Totality and Infinity: The gaze of the Other (the stranger, the widow, and the orphan) radically calls into question my possession of the world, my home; the stranger "disturbs the being at home with oneself." 10 And yet, at the same time, my welcoming response to the Other's gaze ("to recognize the Other is to give") requires my being at home with myself, my ipseity (my identity or selfhood, my not sharing the same horizon with him, which would catch both myself and the Other in a totalizing web). ${ }^{11}$ To put this argument the other way round: There is always a host, but his sovereignty is permanently put in question. Though the stranger presents herself "as the other to the same, who is...always privileged in his own residence" yet, in so presenting herself, she starts from, or speaks for, herself, expressing or disclosing herself rather than being disclosed in a "borrowed light."12 Despite its long history of identification with the host, then, hospitality must also be identified with the Other (in Derrida, as we shall see, even to the extent that the host becomes the guest's hostage!). We can read both identity and difference there, but not one without the other.

Thus rethinking cosmopolitanism from the standpoint of hospitality is not doomed to reproduce identity, to speak only of the host, though it will not end in a self-denying valorization of difference either, in which the host gives way entirely to the guest and the home is lost. Far from being either-ors, identity (host) and difference (guest) are mutually constitutive in hospitality. Indeed, it will be argued that hospitality is the deconstruction in practice of any attempt at stabilizing the binary of identity and difference in cosmopolitanism; "defying dialectics" is both the ethical imperative and lived experience of a cosmopolitanism-as-hospitality which, as a result, must place the decision, and the politics to which decision is always connected, at its heart.

Before developing this argument at length, however, we first need a sense of the increasingly strained articulation of universal and particular in international politics based on state sovereignty. This is important, as the very existence of our binary opposition in the terms that we recognize it today stems from the constitution of the state as the primary locus of those ethical values "for which men are willing to fight and the cultural and political fragmentation of the world into sovereign units that followed."13 


\section{Identity and Difference in International Politics}

The breakdown of modern attempts to reconcile universal and particular through statist approaches to political community is one of the few points of agreement between universalistically inclined liberal cosmopolitans and their attentive-to-difference poststructuralist critics. Liberal cosmopolitan Andrew Linklater will find few in disagreement with his argument - though note the dialectical terms in which it is framed-that the search for new sites for citizenship is ongoing because the sovereign state cannot "reconcile the universal and the particular." 14 Many poststructuralists would also be sympathetic to Linklater's claim that the task of critical social theory is therefore to support the normative ideal of wider, more inclusive forms of political community "which make new articulations of universality and particularity possible." 15

As R. B. J. Walker has argued, the attempt to reconcile universal and particular is what the modern state has always been aboutspecifically, the attempt to resolve a universal notion of humanity with a particularistic notion of political community. This "resolution" involves affirming the "primacy of the particular," the statist community, but also attempts to identify legitimate political authority within these particular communities through a secularized version of claims to universal reason and natural law. ${ }^{16}$ All of which is to say that state sovereignty provides a spatial "solution" to the relation between universality and particularity, claiming that "the good life, guided by universal principles, can occur only within particularistic political communities." 17 Yet many agree that the modern state is no longer able to hold identity and difference in sufficient tension in this way, since contemporary transformations, usually placed under the rubric of "globalisation," have undermined the way in which states, organized spatially, have attempted to close off the possibility of meaningful political community beyond their boundaries. ${ }^{18}$ It is not that territorially defined political community has completely lost its hold-counterhegemonic action in world politics by particularistic identities has itself often reproduced bounded political community as the marginalized seek states for themselves. Nonetheless, these identities push particularity further than the limited pluralism that state sovereignty establishes. In short, nationalism and self-determination can be imagined beyond the life of the nation-state; it is "possible to offer an alternative account of the plurality of peoples than is associated with the restricted pluralism of state sovereignty." 19

Universalists and those suspicious of universalisms agree, then, that the historically specific modern state is inadequate to the task of the 
reconciliation of universal and particular today, though for different reasons. For poststructuralists, reconciliation is not in any case desirable since universalism is always the terms on which "reconciliation" is achieved-state sovereignty establishes only a "limited pluralism" and a paradoxical one at that: Life within states is particularistic even while states make universalistic claims about their authority (sovereignty), and universalistic claims of sovereignty are made in the name of a particular group of citizens rather than universal humanity. ${ }^{20}$ Neither is it indeed possible for reconciliation to be rescued from the modern state (where universalists talk dialectically, by contrast, of achieving "higher levels" of universality and difference $\left.{ }^{21}\right)$, since it is this very state, especially its claim to sovereignty, that constitutes the hope of reconciliation in the first place. When the state as a timeless universal dies, so also does the false hope of a universal structure of particularity-the system of states as a permanent resolution of identity and difference in world politics.

\section{Identity and Difference in Global Civil Society}

For universalists such as Linklater, "post-Westphalian arrangements," which are seen as having the potential for deeper commitments to universality and difference, require "significant inroads into state sovereignty and the concurrent development of transnational citizenry."22 Indeed, from this perspective, cosmopolitan justice requires nothing less than "uncoupling citizenship from the sovereign state so that a stronger sense of moral obligation is felt to all members of the species" rather than just to those who share the same territorial political community. ${ }^{23}$ For this to happen, transnational communities are needed that can develop wider moral allegiances such that exclusive submission to a territorially defined sovereign-the state-begins to appear illegitimate. Enter global civil society. Indeed, Linklater concludes his influential discussion of post-Westphalian forms of political community with the observation that the principles of an international society that have previously reserved full membership only for sovereign states will have to be "modified." The inclusion of nonstate actors is seen as particularly crucial here-providing a future post-Westphalian configuration of Western societies with addressees outside of the West:

A post-Westphalian political order which is not closed in on itself can widen the boundaries of dialogue by recognising that a variety of non-state actors, including non-governmental associations, social movements and national minorities, can enjoy membership of an international society which is not just a society of states but a society 
of peoples and individuals. The promise of solidarism is the partial dissolution of the international society of states within this wider communicative domain. ${ }^{24}$

Here we have universal membership (transnational citizenship) as the basis for the recognition of greater particularity of "peoples" and, ultimately, of individual humans themselves. For poststructuralists such as Walker, differently, today it is necessary to ask what particularist "identities and struggles for autonomy can now be under new historical conditions." And in asking this question, it will become apparent "that structural change in world politics will not take the form of a move from particularity to universality." Indeed, Walker sees the idea of global civil society as useful to universalists precisely for giving an apparently empirical gloss to this move:

Perhaps it is possible to appeal to a rather less abstract and apparently more politically engaged account of an emerging global civil society. Indeed, much of the recent literature attempting to make sense of social movements/world politics has begun to draw quite heavily on the notion of a global civil society, not least so as to avoid falling back on some pre-political or even antipolitical claim about an already existing ethics or world politics. ${ }^{25}$

And indeed, most consumers of the concept of global civil society find the idea seductive precisely because they see in it a successful resolution of universality and particularity. Intimations of global civil society have become by far the most significant attempt to flesh out Linklater's call for a form of universalism that has found a proper place for difference. Take, for example, John Keane on global civil society as a new, universalizable, ethic "beyond borders," which is at one and the same time "a condition of the possibility of multiple moralities - in other words, as a universe of freedom from a Universal Ethic." 26

Thus even those who celebrate the "difference" aspect of global civil society, as Walker notes, are given to "read the construction of world politics as the discovery of similarities elsewhere . . or as a global space that is more or less the same as a statist space, only larger." 27 William Connolly, for example, suspicious as he is of the "single entry" universalism of most cosmopolitanisms, is seduced by a global-civil-society cosmopolitanism that challenges the closures of nationalism "with a more rhizomatic network conception of political culture," a political culture that takes "advantage of the possibilities created by the compression of distance to enact a more vibrant plurality of connections": 
For existing patterns of identification, allegiance and collaboration already exceed the concentric image of them. You might cultivate ties to ecologists or feminists in South America that are more significant than those you share on those two issues with some neighbors, in-laws, or corporate leaders in your own state. You might support cross-country citizen networks designed to protect rain forests in several countries (including your own) to reduce toxic emissions in the world, doing so to nourish the future of life anywhere and everywhere on the planet. You might cultivate extra-state lines of identification with aboriginal peoples, targets of state torture, refugees, or boat people, partly because you extrapolate from experiences of minority standing in your own state to those more radical conditions, partly because your state may have helped to produce the injuries involved, and partly because you realise that cross-state citizen pressure is often needed to modify oppressive state, interstate, and international corporate practices. ${ }^{28}$

This is a characteristic invocation of global civil society in the sense that it moves from the call for ethics to reach beyond borders to the implication that transnational movements are the bearers of a universal ethic. Such a move is the other side of that identified by Walker whereby the state becomes simply the problem for more universal forms of political community, rather than itself an attempt to reconcile universality with particularity.

Attempts to substitute a global politics of civil society for a global politics of states, then, far from transcending the relationship between identity and difference as posited by international society, represents merely another version of the longstanding hope that world politics will involve making the journey from particularity to universality. ${ }^{29}$ Projections of a global civil society are a significant fillip to this perennial hope for they appear to move the cosmopolitan project away from an abstract, top-down universalism, from the theorist-as-legislator mode that has dogged it since Kant, toward a cosmopolitanism of practice, "from below." Thus Richard Falk, for example, writes of the need to move beyond abstract cosmopolitan theory by emphasizing instead "the agency role of global civil society," 30 since this is "the hopeful source of political agency need [ed] to free the minds of persons from an acceptance of state/sovereignty identity." 31 As to the universality of this agency, Falk sees nothing less than an "embedded and emergent consensus" rising from global civil society around "substantive democracy," human rights and nonviolence. ${ }^{32}$ Elsewhere, Falk articulates this universality in terms of global "normative convergence" around visions of a more sustainable, compassionate, and democratic future world order: "The historic role of globalization-from-below is 
to challenge and transform the negative features of globalizationfrom-above." 33

The significance of the idea of global civil society in the terms of identity and difference, then, is that it repeats the dialectical approach of the statist framing of this dichotomy by suggesting that universal and particular are amenable to resolution in the first place. But where the "resolution" enacted by international politics limited the pursuit of universal goods to national political communities, the politics of global civil society appears at last to resolve universal and particular in ways conducive to cosmopolitan political community by advancing a difference-recognizing global ethic. Thus although the global civil society imaginary on one level celebrates a certain diversity of movement, the liberal cosmopolitan reading, by investing the movements of global civil society with a singular ethical project, in fact renders them as different expressions of the same-difference (global civil society), it turns out, is conveniently seeking a new form of universality (cosmopolitan right). The paradoxical dependence of claims to universality that arise from within states on the basis of particularistic groups of citizens is reflected in the claim to ethical universality that arises from within particularistic forms of transnational action. Global civil society, in short, is no more the universal structure of particularity than the state once claimed to be. Indeed, it might be said as much of global civil society as of states that it is only within the secure confines of the particular that it becomes possible to aspire to be universal- "possible to almost forget about the particularity of the community that is shown to be capable of reason and justice, democracy and liberty." 34 At one and the same time (to turn the terms of Linklater's critique of state sovereignty back on him) the universality of global civil society is portrayed in terms that are far too "puffed up" to be plausible, while acknowledgments of its particularity are far too "thin" to successfully incorporate the fact of pluralism in world politics.

In sum, the attempt to provide a universal account of particularity in world politics via the imaginary of global civil society paradoxically reflects the ongoing influence of an international politics defined by state sovereignty on our attempts at thinking cosmopolitan political community. First, there is a similarly dialectical attempt to finally resolve the tension between identity and difference in world politics. Second, this putatively universal resolution is in each case deeply particular. And perhaps none of this should surprise since our understanding of universality and particularity has a history. Our very notions of global identity and difference are produced by, rather than being independent of, international politics. 


\section{Identity and Difference in Cosmopolitanism as Hospitality: Beyond Dialectics}

Liberal cosmopolitanism, to the extent that it seeks to rescue the idea of a universal structure of particularity from the international system, reproduces the underlying dialectical approach to world politics characteristic of the statism it wants to transcend. But before abandoning the attempt to rethink global identity and difference, we should first consider whether thinking dialectically about universality and particularity - as both international and liberal cosmopolitan approaches do under the guise of state sovereignty and global civil society, respectively-is the only option available to us. When we attempt to provide a universal account of difference, particularity is always already known to us, failing in the process to be other at all. But rather than this tempting us to try to transcend universalism in the name of difference-which would ironically merely repeat the dialectical, universalizing move-following Derrida we might substitute universalisms that account for difference with a form of universalism that is always open to difference as truly different or Other-the ethics of hospitality. In Derrida's words, "Justice always addresses itself to singularity, to the singularity of the other, despite or even because it pretends to universality"; and it is hospitality that instantiates this singular address. ${ }^{35}$

On the surface, this move merely repeats the mistake of an account of essentialized otherness in which the fact of plurality is twisted into a universal value. However, Derrida is instead pointing us toward a deconstruction of the binary of identity and difference in the name of a cosmopolitan ethics of hospitality that is irreducible to either pole. Precisely because singularity resists incorporation into any particular account of universality, the cosmopolitanism Derrida has in mind is not identical with an equity reducible to right or law-equity becomes not the abstract, formal equality of liberal cosmopolitanism but, rather, the "equitable honouring of faces," the faces of others whose uniqueness and irreparability (infinity, in Levinasian terms) cannot be thematized and between whom there is "absolute dissymmetry." 36 From this perspective, it is not a matter of a relativistic rejection of universals qua universals but rather of universals that, because they will always fail to be universal enough, must continually be challenged and rethought. This ever-negotiated approach to the application of universals, an approach that calls for decision and therefore for responsibility, is how Derrida appears to distinguish his "cosmopolitics" from liberal cosmopolitanism. The latter sees cosmopolitan practice as defined by an already given ethics and the former as a politics in which silence concerning the "rules" or laws of cosmopolitanism does not suggest the absence of rules as such, rather "the necessity of a leap at the moment of ethical, political, or juridical decision." 37 
The limitless responsibility for the Other expressed in unconditional hospitality defines Derrida's hyperbolic conception of cosmopolitan obligation. Contra liberal autonomy, Derrida works with the notion of freedom from self rather than freedom of the self. ${ }^{38}$ Here, as in much else, Derrida takes from Levinas, for whom freedom is freedom from indetermination, a freedom that the Other invests with meaning. ${ }^{39}$ Freedom is freedom from egotistical "return to the self," a turning away from what, for a creature doomed to destruction, is a perverse obsession with self-preservation toward an answer for the Other, toward a defense of the "rights of the other man." 40 Foregrounding responsibility for the Other in this way flows from an account of the Other pre-existing, and being constitutive of, the self. In Levinas, subjectivity stems from the ego's awareness that it is not sovereign but exists in a world that, far from being an extension of or coinciding with itself, it is fully dependent on. This then allows for a radically decentering experience of the Other and of dependence on the Other, an Other to whom I must therefore now respond (such that subjectivity is defined by openness and vulnerabilityhospitality-rather than Kantian autonomy). Derrida radicalizes further this decentering welcome, suggesting that I am actually constituted by the Other's hospitable welcome of me such that I am now a response to, or hostage of, the Other. ${ }^{41}$

This Other-oriented defense of the "rights of man" (as "rights of the other man") is also necessarily particular ("To th[e] collectivity of comrades we contrast the I-you collectivity which precedes it"42). It is the "right" of the Other to receive a specific hospitable response to his needs arising out of my responsibility for him. ${ }^{43}$ This ethics of hospitality, being attentive to the singularity of the Other, and of the Other's suffering, is therefore irreducible to law or right that are necessarily expressed by the formalism of universality:

I want to insist right away on reserving the possibility of a justice, indeed of a law that not only exceeds or contradicts "law" (droit) but also, perhaps, has no relation to law ...

Law (droit) is not justice. Law is the element of calculation, and it is just that there be law, but justice is incalculable, it requires us to calculate with the incalculable. ${ }^{44}$

The contrast here with Kant's confident claim that "there can be no conflict of politics, as doctrine of right put into practice, with morals, as theoretical doctrine of right," could not be starker. ${ }^{45}$ In the ethics of hospitality, the quantifiable, and therefore universalizable, rights of "man" characteristic of liberal universalism give way to the "practically infinite" right of the Other, a "right" that is irreducible to any law. ${ }^{46}$ Liberal cosmopolitanism, it turns out, is in question not for 
its universalism but rather for failing to be universal enough to encompass the particularity of others whose otherness cannot indeed be thematized; ${ }^{47}$ for assuming a totalized humanity of "interchangeable men," an assumption that "deforms the I and the other who have given rise to it, for it judges them according to universal rules, and thus in absentia." 48 In short, the impersonality with which universality presents itself is yet another instance of inhumanity. ${ }^{49}$

The need to avoid universalism as totalization does not mean, to repeat an important point, that cosmopolitanism as hospitality is absent rules or rights, only the "necessity of a leap at the moment of ethical, political, or juridical decision." Otherwise "we could simply unfold [ethical] knowledge into a programme or course of action"; which, apart from being irresponsible, would also lead us back to totalitarianism. ${ }^{50}$ Contra liberal cosmopolitanism, then, although there can be no formal deduction of politics from ethics, one must, nonetheless, "deduce a politics and a law from ethics. There must be this deduction in order to determine what is 'better' or 'the least bad." "51 Deduction, in this context, is of course decision rather than dialecticslaw and rights must be decided on because there is otherwise nothing to offer the Other, not because the Other is reducible to law or right. A nondialectical cosmopolitanism, one reconciled to the irreducibility of both identity (law) and difference (the Other, before any law), is decisionistic-it is forced back on to the decision.

\section{Cosmopolitanism as Hospitality and the Decision}

The decisionistic quality of cosmopolitan as hospitality that Derrida's defiance of dialectics introduces must at this point be differentiated from the better-known political decisionism of Carl Schmitt, a decisionsim that is anathema to cosmopolitan ethics. Schmitt described the truly political decision as characterized by decision on the state of exception in which ethicolegal, or normative, considerations are subordinated to realpolitik. Here, the survival of the state in a Hobbesian state of nature is all. Schmittian decisionism has absolutely nothing to do with ethical responsibility. Decision regarding who is a friend and who is an enemy is not only completely other than morality in which categories of good and evil might make sense, but is entirely its own foundation. The political, for Schmitt, rests only on this "ultimate distinction" between friend and enemy, and this distinction is one which the state "decides for itself," having "no normative meaning, but an existential meaning only, particularly in a real combat situation with a real enemy" who need be neither evil nor ugly, only "other." ${ }^{2}$ The 
distinctively political decision, then, is simply one regarding "who the enemy is," 53 and he who decides this in the extreme case of war is sovereign:

In any event, that grouping is always political which orientates itself towards this most extreme possibility . . If such an entity exists at all, it is always the decisive entity, and its is sovereign in the sense that the decision about the crucial situation, even if it is the exception, must always necessarily reside there...

However one may look at it, in the orientation toward the possible extreme case of an actual battle against a real enemy, the political entity is essential, and it is the decisive entity for the friendenemy grouping; and in this (and not in any kind of absolutist sense) it is sovereign. ${ }^{54}$

The notion that political decision might actually be necessary to ethical life (as a decision necessitated by hospitable responsibility for the Other), rather than, in Schmittian vein, fundamentally other than or hostile to ethics, is the challenge laid down by Derrida. What distinguishes a Derridean from a Schmittian position is thus not the unfounded, existential quality of the properly political decisionDerrida concurs that "sovereignty is first of all one of the traits by which reason defines its own power." 55 Instead, it is in the ethical relation to the Other or stranger that we should understand the distinction. For Schmitt, the collective (that is public or political) Other, though not necessarily an enemy at any given point in space or time, is always and necessarily capable of becoming an enemy. ${ }^{56}$ And, since "War follows from enmity," the requirement for the "existential negation" of the stranger is an ever-present political possibility. In short, there simply is no ethical relation to the noncitizen Other in politics; cosmopolitanism and politics are antinomies. For Derrida, as we see in more detail below, the very opposite is true. Citizenship, or the inside/outside of political community, attains its significance only inasmuch as it is necessary to an ethical relation to strangers (to ethics as hospitality), manifestly not as a valorization of any political community in and for itself. It is because our responsibility to the Other is definitive of the self, rather than threatening to it, that the boundary between self and Other becomes significant as the threshold of an unconditional hospitality rather than an ever-present possibility of war as in Schmitt.

The necessarily existential quality of the political decision for Derrida then becomes one of deciding, impossibly and therefore singularly each time, how to translate an unconditional hospitality into a practical or conditional hospitality, rather than deciding on the enemy. Thus if the existential quality of the political decision for 
Schmitt is that, like the miracle in theology, it is unfounded in the sense of being pure or referring only to itself, ${ }^{57}$ the existential quality of the political decision for Derrida is that, like the miracle in a different sense, it is in the realm of the impossible and not because it refers only to itself. ${ }^{58}$ It is not irrationalism-"a pure decision not based on reason and discussion and not justifying itself"- -but impossibility that characterizes the decision. The decision is taken not because somebody, in reference to themselves alone, is sovereign enough to decide who constitutes an existential threat but because it is only by making a real, that is, a nondetermined, decision that responsibility for the decision can be taken. And to what or to whom is that responsibility directed? Not toward the preservation of the status quo, as in Schmitt, but toward the Other. For a hospitable ethics defined by responsibility for the Other, the decision is a sine qua non of acting ethically.

Yet although worlds apart from Schmittian decisionism, Derrida is able to rehabilitate the decision (and with it, arguably, the political) from the fate it has suffered in liberal-cosmopolitanism. From a liberal cosmopolitan perspective decisionism is read largely pejoratively, as leaving open a space for a politics that is-dangerously, even fascistically-its own foundation. This is accused of legitimating totalitarian domination and state violence and of rejecting the critical rationality necessary to a critique of these political forms. ${ }^{59}$ On this account, political action should be understood, rather, as the application of a universal ethic orientated around human rights. As Linklater puts it, advocates of liberal cosmopolitan citizenship seek to harness practices that can "transform political communities and the global order so that they conform with universalistic moral commitments ... The universal human rights culture is deemed to reveal the emerging law of world citizens." 60 Thus if Schmittians read "real" politics as pure decisionism or particularity, neo-Kantians read it "ideally" as pure ethics, or a universality characterized not by decision but by imperative. Derrida seeks rather to keep in tension the ideal and the real, the ethics and the politics, and the universal and the particular. We are here "at an equal distance from a simple deduction of politics from ethics and from a sheer pragmatics of politics." 61

Is there a way of describing this decisionistic quality of cosmopolitan obligation in a way that avoids the empty formalism of a critique of dialectics? In his account of hospitality, Derrida gives us just that - a practice rooted in ethical universality that does not merely accommodate difference (where this is always to set the terms for particularity and inevitably, therefore, to privilege a specific form of universality) but which begins with it and must remain open to it. 


\title{
Identity and Difference in Hospitality
}

Derrida reminds us that hospitality is rooted in difference. In order for there to be hospitality there must be a foreigner; and, of course, conversely-that is, for the foreigner to appear foreign there must exist hospitality of some kind.

\begin{abstract}
But for this very reason, and because being at home with oneself supposes a reception or inclusion of the other which one seeks to appropriate, control, and master according to different modalities of violence, there is a history of hospitality, an always possible perversion of the law of hospitality. ${ }^{62}$
\end{abstract}

Despite the origins of the concept of hospitality lying in difference, then, all finite hospitality is constructed around customs, pacts, rights, etc., which reflect the language of the host and which thus also, in a universalizing move, construct the foreigner as the one in need of protection and care in the host's terms. Here, the foreigner risks being little more than the host's own Other, the very "representation of that which is foreign to the host's mode of being-there and who allows the host to identify his own mode of being as proper." 63 Hospitality, then, is always caught up with the "attempt to take care of the foreign question," to account for difference within the host's mode of existence, thereby excluding the foreigner as foreign by reducing him to what is already known. ${ }^{64}$ After all, "It's the familial despot, the father, the spouse, and the boss, the master of the house who lays down the laws of hospitality." 65 Hospitality, it seems, is forever caught between the particularity that is the stranger who comes, and the universalizing move whereby the stranger, in order to be welcomed, must first be translated into the host's own idiom.

In a recent study of this violence at the heart of hospitality, Peter Nyers has described a "sovereign retaking" at work in the Canadian government's response, in 2002, to the activism of Montreal's Comité d'Action des Sans-Statuts (CASS). CASS was formed to stop the deportations of nonstatus Algerians living in Montreal, people whose asylum claims had been rejected but who (in a desperate irony) were not returned due to a Canadian government moratorium on all deportations to a country deemed to be too dangerous. In the face of CASS's successful campaigning on this issue, the Canadian government conceded to nonstatus Algerians the right to make inland applications for permanent residence. Yet in doing so, as CASS activists argued, the Canadian government was at once able to reassert its "sovereign capacity to decide on the exception" by excluding from this agreement those 
nonstatus Algerians living outside Quebec or with any form of criminal record-not to mention those already issued deportation orders, already deported, or unable to pay the costly application fee of $\$ 550$ per adult. As CASS activists noted, given the nature of its concession-namely that these nonstatus applicants were now to be taken as immigrants rather than asylum seekers-the Canadian state was also able to neutralize or capture the campaign to some extent by linking their concession to the "worthiness" or social utility of the applicants rather than the threat of violence facing them in their country of origin. ${ }^{66}$ As Nyers sums up the lessons of the CASS campaign, while activists were successful in receiving recognition from the Canadian government, "they were unsuccessful in defining the conditions of this recognition. The radical takings of foreigners are always at risk of being deflected and absorbed by the . . re-takings of sovereign power." 67

What are we to make of this violence at the heart of our practices of hospitality? To the extent that it involves including the foreigner only on our own terms as hosts, our hospitality is actually not universal enough. True universality in the sense that we are seeking it-universality that is always open to the other as Other-is an entirely unconditional hospitality, a hospitality that is open in advance to "someone who is neither expected nor invited, to whomever arrives as an absolute foreign visitor, as a new arrival, nonidentifiable and unforeseeable, in short, wholly other." 68 This pure hospitality, as Derrida calls it, in setting no limits to the coming of the Other, in its "universal singularity," 69 is more universal than any cosmopolitan law could ever be, being:

beyond rights and laws, beyond a hospitality conditioned by the right of asylum, by the right to immigration, to citizenship, and even by the right to universal hospitality, which still remains, for Kant, for example, under the authority of a political or cosmopolitical law. Only an unconditional hospitality can give meaning and practical rationality to a concept of hospitality. Unconditional hospitality exceeds juridical, political, or economic calculation. ${ }^{70}$

Unconditional hospitality, however, is literally impossible since all finite hospitality implies sovereignty. Without a home we cannot practice hospitality at all. Thus "this concept of pure hospitality can have no legal or political status. No state can write it into its laws":71

This principle [of hospitality] demands, it even creates the desire for, a welcome without reserve and without calculation, an exposure without limit to whoever arrives. Yet a cultural or linguistic community, a family, a nation, can not not suspend, at the least, even betray this principle of absolute hospitality: to protect a "home," without 
doubt, by guaranteeing property and what is "proper" to itself against the unlimited arrival of the other; but also to attempt to render the welcome effective, determined, concrete, to put it into practice. Whence the "conditions" which transform the gift into a contract, the opening into a policed pact; whence the rights and the duties, the borders, the passports and doors, whence the immigration laws. ${ }^{72}$

Paradoxically, then, it is precisely in the name of unlimited hospitality that we have to practice the "perversions" ("that one can become virtually xenophobic in order to protect ... one's own hospitality, the home that makes possible one's own hospitality") of its more limited form. Without limiting our hospitality, we will fail to avoid the "perverse effects" of unlimited hospitality-the loss of home itself. 73 Ensuring that our practices of hospitality stay as true as possible to the law of unconditional hospitality in which we have no home that we call our own requires that we do not in fact surrender our own home but rather render it as accessible as possible, inventing in the process "the best arrangements, the least bad conditions . . . that is to say some particular legislative limits, and especially a particular application of the laws." 74

However, the unconditional law of hospitality continues to haunt us, necessary though our particular application of the law of hospitality undoubtedly is, challenging us to go further, to question whether we should "ask the foreigner to understand us, to speak our language, in all the senses of this term . . . before being able ... to welcome him into our country." 75 This is fundamental since

the foreigner is first of all foreign to the legal language in which the duty of hospitality is formulated, the right of asylum, its limits, norms, policing, etc. He has to ask for hospitality in a language which by definition is not his own, the one imposed on him by the master of the house, the host, the king, the lord, the authorities, the nation, the State, the father, etc. ${ }^{76}$

When asked in an interview whether this could be otherwise, Derrida responds "Yes, because it is perhaps the first violence which the foreigner undergoes: to have to claim his rights in a language he does not speak."77 Note, however, that though Derrida answers the interviewer's question unequivocally in the affirmative, he does not do so with some practical reason why not (a more inclusive framing of law and rights, for example), but because violence has been done, and it is justice beyond violence that must at all costs be thought possible, which must be hoped for. ${ }^{78}$ Given the violence, or lack of justice, in our practices of hospitality, for Derrida we must always think beyond 
hospitality as a pact with certain deserving foreigners toward that unconditional or absolute law of hospitality without which we would lack the concept of hospitality itself and be unable to decide on any laws to condition hospitality. ${ }^{79}$ Indeed, and here we see the mutual necessity of universality and particularity in hospitality, lacking this thought of pure hospitality we would be missing even the idea of the Other, "of the alterity of the other, that is, of someone who enters into our lives without having been invited." 80 Unconditional hospitality is the condition without which limited hospitality-the rights of asylum, refuge, free passage, and so on that define cosmopolitan practice-is unthinkable. Contra dialectical approaches (this is precisely a "nondialectizable antinomy" ${ }^{\prime 1}$ ), we need to see these two hospitalities as both "heterogeneous and indissociable" at the same time: heterogeneous in the sense that the gulf between conditional and unconditional hospitality can never be bridged by any law or rights, by any political or juridical means; indissociable because without laws, rights, and so on there can be no opening of the door to the Other, nothing determinate or concrete to give whatsoever. ${ }^{82}$ This aporia is still the way that must be taken, though precisely for this reason differently or uniquely each time: "This is the double law of hospitality: to calculate the risks, yes, but without closing the door on the incalculable, that is, on the future and the foreigner." 83

\section{Conclusion: \\ Cosmopolitanism as Hospitality}

I have sought to show that enumerating cosmopolitanism dialectically by subsuming global difference within identity (whether by synthesizing particularity into the universality of global civil society or the universality of cosmopolitan right) is incapable of doing justice to particularity in world politics. But we also know that valorizations of particularity are just as dialectical-universalizing accounts of difference that they are. The alternative approach explored here-broadly, Derridean deconstruction-describes the binary of identity and difference in cosmopolitanism as inherently nondialectizable, with each pole as irreducible to as it is indissoluble from the other. It has also been argued that this account of universality and particularity in cosmopolitanism finds its praxis in the ethicopolitics of hospitality, where the infinitely singular Other is nonetheless welcomed only in the context of universalizing law and right. Hospitality, thus described, articulates a cosmopolitanism that "defies dialectics" precisely by placing such undecidability at its heart.

Hospitality "becomes the very name of what opens itself up to the face ... what 'welcomes' it. The face always lends itself to a welcome 
and the welcome welcomes only a face." 84 And just as surely as the face of the Other calls for hospitality (to the extent, indeed, that ethics is hospitality), hospitality produces not totality but undecidability. This is because this face of the Other

as we know from reading Levinas, must resist all thematization ... This irreducibility to a theme, this exceeding of all thematization ... is precisely what the face has in common with hospitality. Levinas does not simply distinguish hospitality and thematization . . he explicitly opposes them. ${ }^{85}$

But despite not being able to thematize hospitality without doing violence to the infinity of the Other, hospitality must be practiced at the risk of an even worse violence in a world defined by inhospitality. To practice in the absence of thematization, as Derrida shows, is the very terrain of undecidability. Undecidability here brings the political back in to cosmopolitanism because it means having to decide uniquely and responsibly each time exactly how to offer a hospitality that, in the very offering, will reduce the stranger to a theme, to a guest in the (sovereign) home. This problematic, or double-bind, of hospitality is the deconstruction in practice of any attempt at stabilizing the binary of identity-difference in cosmopolitanism; and it turns cosmopolitanism from a pure ethics into an ethico-politics. "Defying dialectics," it turns out, is at once the ethical imperative and the political practice of a hospitality that is cosmopolitan, indeed, of a cosmopolitanism that is hospitality.

\section{Notes}

1. Jens Bartelson, "The Trial of Judgment: A Note on Kant and the Paradoxes of Internationalism," International Studies Quarterly 39 (1995): 276.

2. Andrew Linklater, "The Evolving Spheres of International Justice," International Affairs 75, no. 3 (1999): 481.

3. Jurgen Habermas, The Philosophical Discourse of Modernity, translated by Fredrick Lawrence (Cambridge MA: MIT Press, 1987), p. 284.

4. Hedley Bull, The Anarchical Society (London: Macmillan, 1977).

5. Nick Vaughan-Williams, "Beyond a Cosmopolitan Ideal: The Politics of Singularity," International Politics, 44 (2007): 107-124.

6. Emmanuel Levinas, Totality and Infinity: An Essay on Exteriority, translated by Alphonso Lingis (Pittsburgh: Duquesne University Press, 1969), pp. $87,102$.

7. Jacques Derrida, Adieu: To Emmanuel Levinas, translated by PascaleAnne Brault and Michael Nass (Stanford, CA: Stanford University Press, 1999), p. 49.

8. Levinas, Totality and Infinity, note 6, p. 27.

9. "The relation with infinity respects the total Transcendence of the other without being bewitched by it," ibid., p. 78. 
10. Ibid., p. 39.

11. Ibid., p. 76. See also p. 37. Thus the home of which hospitality speaks is deconstructable (we can destabilize hospitality's binary terms of subjectobject, self-other, host-guest) but not dissolvable.

12. Ibid., pp. 75, 67.

13. Bartelson, "The Trial of Judgement," note 1, pp. 262-263.

14. Andrew Linklater, The Transformation of Political Community (Cambridge, UK: Polity, 1998), p. 201.

15. Ibid., p. 49.

16. R. B. J. Walker, Inside/Outside: International Relations as Political Theory (Cambridge, UK: Cambridge University Press, 1993), pp. 61-62.

17. Ibid., p. 64.

18. Ibid., p. 13.

19. Ibid., p. 77.

20. Ibid., pp. 63, 77.

21. Linklater, The Transformation of Political Community, note 14, p. 17.

22. Ibid., p. 181.

23. Ibid., p. 204.

24. Ibid., p. 209.

25. R. B. J. Walker, "Social Movements/World Politics," Millennium 23, no. 3 (1994): 674.

26. John Keane, Global Civil Society (Cambridge, UK: Cambridge University Press, 2003), p. 196.

27. Walker, "Social Movements/World Politics," note 25, p. 690.

28. William E. Connolly, "Speed, Concentric Cultures and Cosmopolitanism," Political Theory 28, no. 5 (2000): 604.

29. Walker, Inside/Outside, note 16, pp. 77-78.

30. Richard Falk, "Global Civil Society and the Democratic Project," in B.

Holden, ed., Global Democracy: Key Debates (London: Routledge, 2000), p. 171.

31. Richard Falk, On Humane Governance: Towards a New Global Politics (Philadelphia: Pennsylvania University Press, 1995), p. 101.

32. Falk, "Global Civil Society and the Democratic Project," note 30, pp. 172-174.

33. Ibid., pp. 164-165.

34. Walker, Inside/Outside, note 16, p. 177. Though, as we shall see, for Jacques Derrida this is an irreducible problematic (see, for example, Derrida, The Other Heading: Reflections on Today's Europe, translated by P. A. Brault and M. B. Naas [Bloomington: Indiana University Press, 1992] pp. 72-73).

35. Jacques Derrida, "Force of Law: 'The Mystical Foundation of Authority," Cardozo Law Review 921 (1990): 955.

36. Ibid., p. 959.

37. Derrida, Adieu, note 7, p. 117. See also Jenny Edkins and Maja Zehfuss ("Generalising the International," Review of International Studies 31 [2005]: 460-461), who argue using Derrida that undecidability, and the ways in which this paradoxically calls for decision, is the very condition of politics.

38. M. Bankovsky, "Derrida Brings Levinas to Kant," Philosophy Today 49, no. 2 (2005): 161.

39. Levinas, Totality and Infinity, note 6, p. 88. See also Levinas, Existence and Existents, translated by A. Lingis (London: Kluwer, 1995), p. 94.

40. Levinas, Totality and Infinity, note 6, p. 124.

41. Bankovsky, "Derrida Brings Levinas to Kant," note 38, pp. 157-158.

42. Levinas, Existence and Existents, note 39, p. 95. 
43. Bankovsky, "Derrida Brings Levinas to Kant," note 38, p. 159.

44. Derrida, "Force of Law," note 35, p. 925.

45. Immanuel Kant, Practical Philosophy, translated by M. J. Wood (Cambridge: Cambridge University Press, 1999), p. 388. For a helpful discussion comparing Kant and Derrida in this regard, see M. La Caze, "At the Intersection: Kant, Derrida, and the relation between ethics and politics," Political Theory 35, no. 6 (2007): 783.

46. Derrida, "Force of Law," note 35, p. 971.

47. Jacques Derrida, "The World of the Enlightenment to Come (Exception, Calculation, Sovereignty)," Research in Phenomenology 33 (2003): 49.

48. Levinas, Totality and Infinity, note 6, pp. 298, 300.

49. Ibid., p. 46.

50. Derrida, Adieu, note 7, p. 117.

51. Ibid., p. 198.

52. Carl Schmitt, The Concept of the Political (Chicago: University of Chicago Press, 1996), pp. 26, 27.

53. Ibid., p. 34; see also pp. 45, 47.

54. Ibid., p. 39.

55. Derrida, "The World of the Enlightenment to Come," note 47, p. 45. 56. Schmitt, The Concept of the Political, note 52, p. 33.

57. Carl Schmitt, Political Theology (Chicago: University of Chicago Press, 2005), p. 36; see also pp. 12, 13.

58. Ibid., p. 66.

59. Jurgen Habermas, The New Conservatism: Cultural Criticism and the Historians' Debate (Cambridge, MA: MIT Press, 1989).

60. Linklater, The Transformation of Political Community, note 14, p. 124.

61. F. Raffouel, "On Hospitality: Between Ethics and Politics," Research in Phenomenology 28 (1998): 282.

62. Jacques Derrida, On Cosmopolitanism and Forgiveness (London: Routledge, 2001), p. 17.

63. S. E. Kelly, "Derrida's Cities of Refuge: Toward a Non-Utopian Utopia," Contemporary Justice Review 7, no. 4 (2004): 429.

64. Ibid., p. 429.

65. Jacques Derrida, Of Hospitality (Stanford, CA: Stanford University Press, 2000), p. 149.

66. Peter Nyers, "Abject Cosmopolitanism: The Politics of Protection in the Anti-Deportation Movement," Third World Quarterly 24, no. 6 (2003): $1086-1087$.

67. Ibid., p. 1090.

68. Derrida, in G. Borradori, Philosophy in a Time of Terror: Dialogues with Jurgen Habermas and Jacques Derrida (Chicago: University of Chicago Press, 2003), p. 129.

69. Derrida, Of Hospitality, note 65, p. 79.

70. Derrida, "The World of the Enlightenment to Come," note 47, p. 40.

71. Borradori, Philosophy in a Time of Terror, note 68, p. 129.

72. Jacques Derrida, "The Principle of Hospitality," Parallax 11, no. 1 (2005): 6, emphasis added.

73. Derrida, Of Hospitality, note 65, p. 53.

74. Derrida, "The Principle of Hospitality," note 72, p. 6.

75. Derrida, On Cosmopolitanism, note 62, p. 15.

76. Derrida, Of Hospitality, note 65, p. 15.

77. Derrida, "The Principle of Hospitality," note 72, p. 7. 
78. Ibid., p. 7.

79. Borradori, Philosophy in a Time of Terror, note 68, p. 129.

80. Ibid., p. 129.

81. Derrida, Of Hospitality, note 65, p. 77.

82. Borradori, Philosophy in a Time of Terror, note 68, p. 129.

83. Derrida,"The Principle of Hospitality," note 72, p. 6.

84. Derrida, Adieu, note 7, p. 20.

85. Ibid., p. 20. Indeed, in Totality and Infinity, Levinas suggests that the "possibility of forgetting the transcendence of the Other" is the same thing as "banishing with impunity all hospitality ... from the home" (pp. 172-173; see also Levinas "The Nations and the Presence of Israel" in In the Time of Nations, translated by M. Smith [Bloomington: Indiana University Press, p. 98]). 